

\section{DISCLAIMER}

This report was prepared as an account of work sponsored by an agency of the United States Government. Neither the United States Government nor any agency Thereof, nor any of their employees, makes any warranty, express or implied, or assumes any legal liability or responsibility for the accuracy, completeness, or usefulness of any information, apparatus, product, or process disclosed, or represents that its use would not infringe privately owned rights. Reference herein to any specific commercial product, process, or service by trade name, trademark, manufacturer, or otherwise does not necessarily constitute or imply its endorsement, recommendation, or favoring by the United States Government or any agency thereof. The views and opinions of authors expressed herein do not necessarily state or reflect those of the United States Government or any agency thereof. 


\section{DISCLAIMER}

Portions of this document may be illegible in electronic image products. Images are produced from the best available original document. 
Page 2

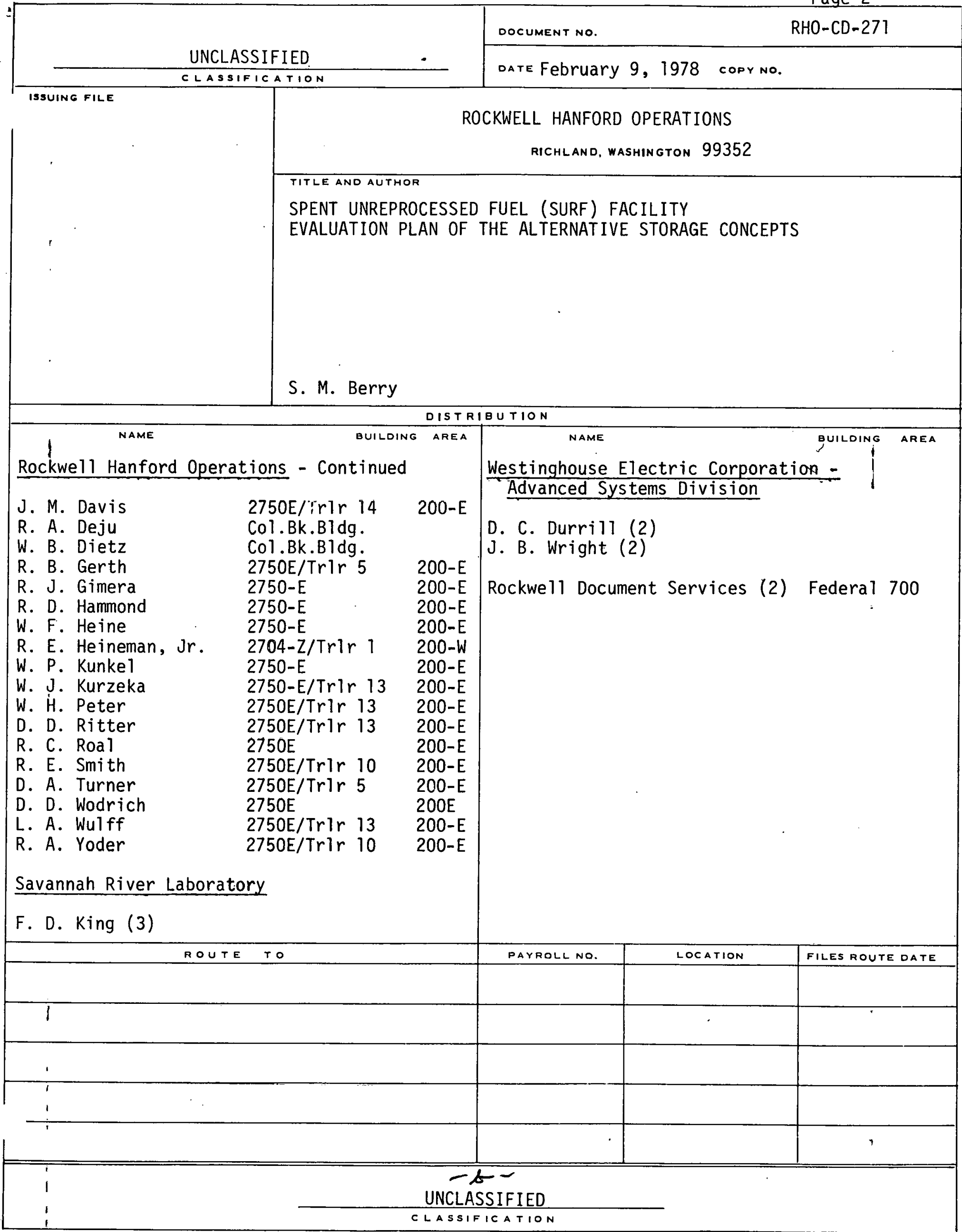




\title{
SPENT UNREPROCESSED FUEL (SURF) FACILITY \\ EVALUATION PLAN OF THE ALTERNATIVE STORAGE CONCEPTS
}

\author{
Prepared By: \\ S. M. Berry \\ SURF Engineering \\ Design Engineering Department
}

Approved By:

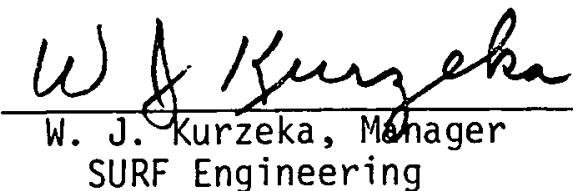

This report was prepared an account of work sporsored by the United States Government. Neither the Enited Stres nor the United States Department of Energy, nor any of their employees, nor any of their contractors, subcontractors, of their employeses, makes any warranty, express or implied, or assumes any lepal liability or responsibility for the accuracy, completeness or usefulness of any information, apparatus, produet or process disclosed, or represents that its use prould or infringe privatefy owned rights.

February 9, 1978

This Report was prepared as an account of work sponsored by the United States Government. Neither

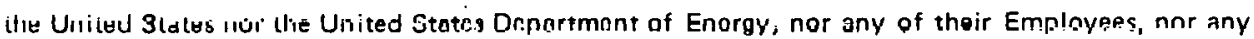
of their Contractors, Subcontractors, or their Employees, makes any warranty, express or implied, or assumes any legal llabllity ur tespurisibility fü llie acsiviacy, completenc 33, or usafulnosc of any in. formation, apparatus, product or process disclosed, or represents that its use would not infringe privately owned rights.

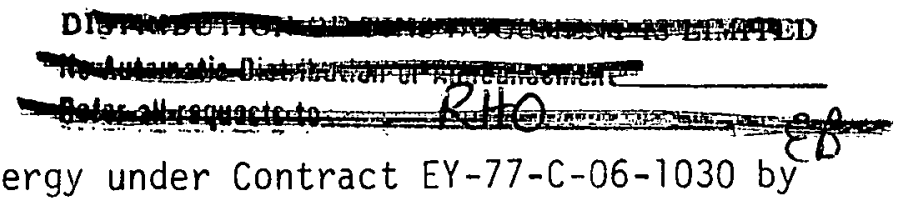

Operated for the U. S. Department of Energy under Contract EY-77-C-06-1030 by Rockwe11 International Atomics International Division Rockwell Hanford Operations Richland, Washington 99352 
TABLE OF CONTENTS

$\begin{array}{llc} & & \frac{\text { Page }}{1} \\ 1.0 & \text { INTRODUCTION } & 1 \\ 2.0 & \text { PURPOSE } & 1 \\ 3.0 & \text { EXPECTED RESULTS } & 1 \\ 4.0 & \text { RATING SYSTEM INSTRUCTIONS } & 2 \\ 5.0 & \text { RATING OF CONCEPTS } & 3-31 \\ 6.0 & \text { CONCEPT EVALUATION SUMMARY SHEET } & 32\end{array}$




\section{SPENT UNREPROCESSED FUEL FACILITY \\ EVALUATION PLAN OF THE ALTERNATIVE STORAGE CONCEPTS}

\section{$\underline{1.0 \quad \text { INTRODUCTION }}$}

Studies have been made of seven alternative concepts for the storage of unreprocessed spent nuclear fuel in a retrievable surface storage facility. The results of these studies are reported in Document RHO-LD-2, February 1978, "Spent Unreprocessed Fuel Facility Engineering Studies of Storage Concepts." Engineering details of each concept are not fully developed in certain areas, and various features of the concepts will be improved by further study and optimization as the conceptual design is expanded. However, the Engineering Studies document contains sufficient information to permit an evaluation and selection of a preferred concept and a recommendation for a second choice concept for further development.

This evaluation plan has been used by Rockwell Hanford Operations (Rockwel1) engineering personnel to assist them in making the selection of the Spent Unreprocessed Fuels (SURF) storage concept that is to be recommended to the U. S. Department of Energy - Richland Operations (DOE-RL). This document was first issued within Rockwell as a working paper in draft form. Concept selection team members received and reviewed the documentation on SURF storage concepts and then they filled out the evaluation sheets according to their best judgement. The numerical ratings from the individual concept evaluation - summary sheets were averaged and are incorporated in this document. The result of this evaluation was that the Drywe 11 Concept was rated highest with the Water Basin Concept and the Sealed Storage Cask Concept with multiple canisters of SURF coming in a close second and third in rating.

\subsection{PURPOSE}

The purpose of this document is to provide a systematic format for making a concept selection from the seven alternative concepts presented in the RHO-LD-2 Document. This document, in its present form, does not make a recommendation as to a preferred concept, but only provides a numerical method for evaluation of the concepts to aid in arriving at a selection.

\subsection{EXPECTED RESULTS}

Ideally, all persons evaluating the concepts for the first time will choose the same concept and will have a numerical basis for supporting their selection. However, this need not always be the case, and failure to obtain early agreement is not necessarily regarded as a bad result. This rating system is provided as a working tool to be used by the engineering personnel involved in 
the SURF Program in reaching their own decisions. It is structured so that the critical features of ali concepts will be considered by the evaluators. This will also permit areas of disagreement to be isolated and resolved.

\subsection{RATING SYSTEM INSTRUCTIONS}

The concept evaluation system proposed herein is to be used in conjunction with the Engineering Studies document (RHO-LD-2), along with an additional knowledge or opinions that might be held by the person making the evaluation. The steps to be performed in using the SURF concept evaluation system are as follows:

Step 1

Assign a weight to the particular feature covered by each evaluation sheet. The assignment of greater weight to a given feature will permit it to have a greater potential effect on the overall rating of the concepts. Suggested weights are given on each sheet; however, the evaluator is free to assign different weights at his own discretion. Before proceeding beyond Step 1, a group of evaluators must agree initially on the weights to be given to the feature covered by each evaluation sheet.

Step 2

Review the evaluation sheets for completeness. The evaluator may add features if he believes they are needed; blank evaluation sheets are provided for this purpose. Features to be deleted should be assigned a weight of zero.

\section{Step 3}

Transfer the ratings to the summary sheet and add the ratings for each concept to obtain the reilative overall standings. The concept with the highest score should be the one recommended for further study. The concept with the second highest score should be recommended for the back-up position.

A listing of all the features to be evaluated is shown on the Evaluation. Summary Sheet at the end of this document. Space for adding additional features is also provided on this summary sheet. 


\section{METHOD OF SURF CONFINEMENT}

Sheet A

Suggested Weight, 40; Assigned Weight 40.

\section{REQUIREMENTS}

Waste releases to the environment are required to be "as low as reasonably achievable" which is defined by Appendix I of 10 CFR 50 .

\section{COMPLIANCE}

At least two confinement barriers will be installed between the stored spent fuel assembly and the environment.

Sealed Storage Cask Concept (Ventilated) (SSCC-RSSF)

First barrier - welded carbon steel canister

Second barrier - welded carbon steel overpack

Sealed Storage Cask Concept (Nonventilated and with Single

Canister of SURF) (SSCC-1)

First barrier - welded carbon steel canister

Second barrier - concrete cask (steel lined)

Sealed Storage Cask Concept (Nonventilated and with Multiple Canisters of SURF) (SSCC-2)

First barrier - welded carbon steel canister

Second barrier - concrete cask (steel lined)

Air-Cooled Vault Concept (ACVC)

First barrier - welded carbon steel canister

Second barrier - welded carbon steel overpack

Drywell Concept (DWSC-T)

First barrier - welded carbon steel canister

Second barrier - carbon steel pipe with sealed cover and grouted bottom 
Drywell Concept (With Heat Pipes) (DWSC-2)

First barrier - welded carbon steel canister

Second barrier - steel lined concrete vault, including lower portion of heat pipe, with sealed bolted access plugs

Water Basin Concept (WBSC)

First barrier - cooling pool water

Second barrier - surrounding building with associated ventilation and confinement systems 


\section{RADIATION PROTECTION}

Sheet $B$

Suggested Weight, 40; Assigned Weight 40

\section{REQUIREMENTS}

Evaluations on this sheet should be limited to consideration of direct radiation from fixed sources. Exposure due to possible radioactive effluents is covered under "Confinement," Sheet A.

Operating personnel shall not receive total radiation exposure in excess of that permitted by U.S. Department of Energy (DOE) Manual Chapter. 0524. Members of the general public shall not receive total radiation exposure in excess of that permitted by 10 CFR 100 .

\section{COMPLIANCE NOTES}

Operating personnel are protected by shielding, geometry, and appropriate distances. Appropriate warning devices and clearly defined isolation are provided for potential radiation zones. The general public is excluded from significant exposure to fixed radiation sources.

Rating

Sealed Storage Cask Concept (Ventilated) (SSCC-RSSF)

Operating Personnel - Protection during storage is provided by a large mass of concrete and steel in the canister/cask walls. Lead baffles will be provided over the ventilation openings to block radiation streaming.

General Public

- Protection from direct sources is provided. primarily by exclusion from the facility. The bulk shielding provided for personnel is a second protection. 
Sealed Storage Cask Concept (Nonventilated and with Single Canister of SURF) (SSCC-1)

Operating Personnel - Protection is provided by the large mass of concrete in the cask walls once the cask is loaded. During the loading operation, protection is provided by hot cell shielding equipment.

General Public - Protection from direct sources is provided primarily by exclusion from the facility. The bulk shielding provided for operating personnel is a second protection.

Sealed Storage Cask Concept (Nonventilated and with Multiple Canisters of SURF) (SSCC-2)

Operating Personnel - Same as single canister assembly (SSCC-1)

General Public - Same as single canister assembly. (SSCC-1)

Air-Cooled Vault Concept (ACVC)

Operating Personnel - Protection during storage is provided by thick concrete walls around the vault. Protection during assembly, placement, and removal is provided by transporter shield and a movable shield when the air access port into the vault is open.

General Public - Protection is provided by the remoteness of the facility and the bulk shiclding which protects the operating personnel.

Drywe 11 Concept (DWSC-1)

Operating Personnel - Protection during storage is provided by thick concrete 1 id and large slant thickness of earth around buried pipe. Protection during. placement is provided by the shielded transporter vehicle and a movable shield when the lid to the drywell is open.

General Public - Protection is provided by the remoteness of the facility and the bulk shielding which protects operating personnel. 
Drywell Concept (With Heat Pipes) (DWSC-2)

Operating Personnel - Same as preceding concept

General Public - Same as preceding concept

Water Bas in Concept (WBSC)

Operating Personnel - Protection during storage, transfer, and unloading operations is provided by the depth of water cover over bare fuel assemblies and concrete pool walls.

General Public

- Protection is provided by the remoteness of the facility and the shielding which is provided to protect the operating personnel. 


\section{RESISTANCE TO CREDIBLE EVENTS}

Sheet $\mathrm{C}$

Suggested Weight, 40; Assigned Weight 40

\section{REQUIREMENTS}

Maximum credible events or accidents must be identified and the facility must be designed to resist such events and recover from their after-effects without loss of containment or heat rejection system.

Natural Phenomenon: Naturally occurring events such as tornado, earthquakes, floods, etc., which would present a hazard to safe site operation.

Remaining Credible Events: Events, other than natural phenomenon, which present a hazard to safe site operation and have a sufficiently high probability of occurrence to warrant including engineered safety features to mitigate the consequences of these events.

Sealed Storage Cask Concept (Ventilated) (SSCC-RSSF) $\underline{\text { Rating }}$ Natural Phenomenon The heavy concrete and steel cask prevents damage to the assembly canister during any credible natural occurring event.

Remaining Credible Events - The passive nature of the heat removal mechanism permits continued cooling of the fuel assembly following any credible event. Since the heat removal capability for the assembly can be maintained, release of fission products following any credible event is not considered feasible; however, the natural draft mode of air cooling is subject to variations in flow rate due to interruption by unusual local meteorological conditions or blockage of the vent openings. 
Sealed Storage Cask Concept (Nonventilated and With Single

\section{Canister of SURF) (SSCC-1)}

Natural Phenomenon

- The heavy concrete and steel cask prevents damage to the assembly canister during any conceivable natural

occurrence

Remaining Credible Events - The passive nature of the heat removal mechanism permits continued cooling of the fuel assembly following any credible event. Since the heat removal capability for the assembly can be maintained, release of fission products following any credible event is not considered feasible.

Sealed Storage Cask Concept (Nonventilated and With Multiple Canisters of SURF) (SSCC-2)

Natural Phenomenon

- The same resistance as provided by preceding concept (SSCC-1).

Remaining Credible Events

- The same as preceding concept; however, this concept would need to consider the potential for criticality upon rearrangement and/or flooding of the enclosed.

SURF.

Air-Cooled Vault Concept (ACVC)

- The massive reinforced cuncrele walls. provide protection from external perturbations. The natural draft mode of air cooling is subject to variations in flow rate due to interruption by unusual local meteorological conditions. Because of these problems, Lhis cooling mechanism needs further detailed study to evaluate its effectiveness. However, the large heat capacity of the fue 1 assemblies and the vault allow interruptions of several hours without damage to the stored fuel assemblies. 
Remaining Credible Events - Other events that may cause disruption of some aspect of this storage scheme would create a formidable maintenance and/or repair problem as a 11 work must be conducted behind heavy shielding materials using remote handling devices. However, no credible event can cause loss of confinement of the contained fission products.

Drywe 11 Concept (DWSC-1)

Natural Phenomenon

- The caisson is inherently quite immune to natural occurrences as the top of - the assembly is approximately 10 feet below ground level. No credible natural phenomenon could cause loss of confinement of the contained fission products.

Remaining Credible Events - No credible event can cause the release of contained fission products, however, the potential for ground water leaking into the caisson and causing a corrosion problem must be addressed in the design.

Urywe 11 Concept (With Heat Pipes) (DWSC-2) Natural Phenomenon

- The same resistance as provided by preceding drywe 11 concept (DWSC-1), except a detailed safety analysis is required to determine how much hardening is required to protect the portion of the heat pipe above ground.

Remaining Credible Events - The same resistance is provided by the single assembly caisson. However, the criticality potential must be addressed. Also, the fluid in the heat pipes used to cool the fuel assemblies requires further analysis and testing to determine extent of the radiation damage to the heat transfer media. 
Water Basin Concept (WBSC)

Natural Phenomenon

- The design of the water basin for all credible natural phenomenon presents no special problem as the design of spent fuel pools has matured with the commercial nuclear power industry.

Remaining Credible Events - The safety hazards associated with waterfilled fuel pools have al ready been thoroughly evaluated by the commercial nuclear power industry and sufficient criteria presently exists to assure an acceptably safe design. 


\section{HEAT REJECTION SYSTEM}

Sheet $D$

Suggested Weight, 40; Assigned, Weight 40

\section{REQUIREMENTS}

Fuel assembly cladding temperature shall be maintained below $705^{\circ} \mathrm{F}$ to assure cladding integrity during the storage of SURF. Continuous heat removal capability must be maintained in order not to exceed the $705^{\circ} \mathrm{F}$ temperature limitation.

COMPLIANCE

All storage concepts provide a dependable heat removal mechanism with sufficient capacity to assure that fuel assembly cladding temperatures do not exceed $705^{\circ} \mathrm{F}$ following any credible event.

Sealed Storage Cask Concept (Ventilated) (SSCC-RSSF) 30

This concept requires both conductive cooling through the canister walls and convective cooling by air flow through the annular area via vent openings. Because the heat density of SURF is much lower than that of high-level waste, and because of the poor basic heat transfer of SURF in air, it may be difficult to make economical use of this concept. In addition, the potential exists for blockage of the vent openings which could pose a serious problem.

Sealed Storage Cask Concept (Nonventilated and With Single Canister of SURF) (SSCC-1)

This concept depends solely on passive heat transfer mechanisms of radiation, convection, and conduction to reject the heat of the fuel assembly. Minimum of maintenance and monitoring are required to verify proper function of the heat rejection system.

Sealed Storage Cask Concept (Nonventilated and With Multiple Canisters of SURF) (SSCC-2)

The same as single canister concept (SSCC-1). 
Air-Cooled Vault Concept (ACVC)

This concept depends solely on passive convective and radiative heat transfer mechanisms. No credible long-term phenomenon can sufficiently inhibit these mechanisms from providing sufficient cooling to cause overheating of the fuel assemblies; however, more detailed investigation of this heat removal system is required to determine its sensitivity to local wind conditions, as well as periodic maintenance to remove debris that may accumulate in and around the air passages.

Drywell Concept (DWSC-1)

This system relies solely on passive radiative and conductive heat transfer mechanisms to cool the stored canisters. No credible event could interrupt this cooling and cause damage to the stored assembly.

Drywell Concept (With Heat Pipes) (DWSC-2)

This concept uses a heat pipe as the primary heat transfer mechanism. The fluid in the heat pipes used to $\mathrm{cool}$ the fuel assembiies requires further analysis and testing to determine the extent of radiation damage to the heat transfer media.

Water Basin Concept (WBSC)

This is the only concept utilizing an active mechanical heat removal system. However, an active system should not be considered a safety liability as the storage pool water provides approximately four weeks supply of water for boil-off, and sustained emergency cooling can be provided by simply adding makeup water while the mechanical heat removal system is repaired. 


\section{OPERATING RELIABILITY}

Sheet $E$

Suggested Weight, 30; Assigned Weight 30

\section{REQUIREMENTS}

Safe storage with minimum of attendance and services is required to assure maximum reliability.

\section{COMPLIANCE}

All storage concepts require some type of surveillance and monitoring to assure continued safe functioning. All storage schemes utilizing canisters require periodic monitoring to locate and repair leaking canisters.

Sealed Storage Cask Concept (Ventilated) (SSCC-RSSF)

Surveillance and monitoring of the air leaving the cask is required

to determine if fission products are leaking from the contained storage canister. In addition, monitoring of the annulus area between the canister and overpack also required. Also, periodic removal of debris consisting of wind-blown soil and vegetation is required to keep air passages open.

It should be pointed out that actual measurement of vent air to locate leaking fission products may prove to be quite difficult or expensive, and/or both.

Sealed Storage Cask Concept (Nonventilated and With Single Canister:

$$
\text { of SURF) (SSCC-1) }
$$

The periodic sampling of the interior annulus for monitoring the storage canister is the only operating requirement.

Sealed Storage Cask Concept (Nonventilated and With Multiple Canisters of SURF) (SSCC-2)

The same requirements as for the single canister concept (SSCC-1). 
Air-Cooled Vault Concept (ACVC)

The attention required of this facility is radiation monitoring of the vault, annulus area between the canister and overpack, and vent stack air; and periodic inspections and maintenance of the vault to:

1. Inspect all air passages and remove any blockage

2. Inspect for water accumulation and remove accumulated debris.

Drywell Concept (DWSC-1)

The periodic sampling and measurement of the atmosphere inside the caisson is required to determine if canister integrity has been breached.

Drywe 11 Concept (With Heat Pipes) (DWSC-2)

The same as for the single assembly (DWSC-1), but periodic maintenance and/or replacement of heat pipes may also be required.

Water Basin Concept (WBSC)

The mechanical heat removal system and associated power supply (both normal and emergency), the water clean-up system and the chemistry control system all require the attention of operators and maintenance personnel. Also, the heating and ventilation exhaust systems require continuous monitoring. 


\section{RETRIEVABILITY}

Sheet $F$

Suggested Weight, 30; Assigned Weight 30

\section{REQUIREMENTS}

The stored fuel assemblies must be retrievable after 50 years storage. The storage concept should endeavor to make retrieval simple with a minimum of hazard to operating personnel, and at the same time not create excessive secondary waste.

COMPLIANCE

All of the storage concepts provide for retrieval of stored assemblies. However, each concept has a different degree of complexity involved with retrieval operations and disposal of activated and/or contaminated materials.

Sealed Storage Cask Concept (Ventilated) (SSCC-RSSF) Rating

Retrieval - This requires a hot cell and associated handling equipment.

Waste - The potential does exist for contamination of the canister, overpack, and possibly the cask.

Sealed Storage Cask Concept (Nonventilated and With Single Canister of SURF) (SSCC-1)

Retrieval - Same potential as for ventilated cask concept (SSCC-RSSF) Waste - Same potential as for ventilated cask concept (SSCC-RSSF), except for the overpack.

Sealed Storage Cask Concept (Nonventilated and With Multiple Canisters of SURF) (SSCC-2)

Retrieval - Same as preceding concept

Waste - Essentially the same potential as preceding concept; however, it should be noted that the quantity of contaminated material (concrete and steel) that could possibly be generated per SURF assembly is less for the multiple concept approach. 
Air-Cooled Vault Concept (ACVC)

Retrieval - The same requirements as the ventilated storage cask (SSCC-RSSF)

Waste - Essentially the same problems as with the ventilated storage cask (SSCC-RSSF), but the vault materials may become contaminated and could require in situ decay or disposal. In situ decay would require sealing the vault against personnel.

Drywell Concept (DWSC-1)

Retrieval - The same requirements as the ventilated cask concept (SSCC-RSSF)

Waste - Along with the activation of the pipe casing, the concrete and surrounding ambient soil could become contaminated.

Drywe 11 Concept (With Heat Pipes) (DWSC-2)

Retrieval - The same as with the preceding dry wel1 concept (DWSC-1)

Waste - The waste generation would be the same as in preceding. concepts, i.e., contamination of the canister and surrounding concrete. In addition, the heat pipe(s) and working fluid could also become contaminated.

Water Basin Concept (WBSC)

Retrieval - The SURF assemblies are visible for direct handling as well as the overpack canisters for leakers that are associated with these assemblies.

Waste - The fuel racks could become contaminated. The fuel pool walls, water handling equipment and piping could also become contaminated. 


\section{LEAKAGE MONITORING}

Sheet $G$

Suggested Weight, 20; Assigned Weight 30

\section{REQUIREMENTS}

A technique is required to verify that the fission products contained in the stored fuel assemblies do not leak to the environs.

\section{COMPLIANCE}

All of the storage concepts include a method of leakage monitoring to provide assurance that both fission product barriers are not breached.

Sealed Storage Cask Concept (Ventilated) (SSCC-RSSF) Rating

The annular exhaust air will periodcally sampled and measured to determine if the SURF canister with overpack is leaking. However, because of the very low air flow rates through the annulus, implementation of this type of monitoring scheme may prove to be quite difficult. Also, the annular area between the canister and overpack will be monitored.

Sealed Storage Cask Concept (Nonventialted and With Single Canister

$$
\text { of SURF) (SSCC-1) }
$$

The atmosphere inside the cask will be sampled periodically via sampling tube and examined for radionuclides.

Sealed Storage Cask Concept (Nonventilated and With Multiple Canisters of SURF (SSCC-2)

The same procedure as in precedina concept (SSCC-1).

Air-Cooled Vault Concept (ACVC)

The cooling air in the vault which is discharged through the stack will be continuously monitored for radionuclides. Precise location of leaking assembly will require development of a system capable of identifying the location of the leaking fuel assembly canister. Also, the annulus between the canister and overpack will be monitored. 
The atmosphere in the caisson will be periodically sampled to assure integrity of the canister.

Drywe11 Concept (With Heat Pipes) (DWSC-2)

The same as with the preceding concept (DWSC-1).

Water Basin Concept (WBSC)

The H\&V discharge will be continuously monitored to assure that release of gaseous radionuclides is maintained as low as reasonably achievable. The pool design also incorporates a leakage collection system to contain all liquid leakage from the pool. The pool water will be continuously monitored to detect increases in radioactivity. Ion exchangers and filters will be provided to remove radionuclides and impurities from the pool water. 


\section{STATUS OF TECHNOLOGY}

Sheet $H$

Suggested Weight, 20; Assigned Weight 20

\section{REQUIREMENTS}

Because of the large amounts of fission products and fissionable materials contained in the stored assemblies, the facility design should incorporate state-of-the-art technology.

\section{COMPLIANCE}

Each storage scheme uses state-of-the-art technology to the maximum extent possible for that particular concept.

Sealed Storage Cask Concept (Ventilated) (SSCC-RSSF) Rating Heat removal is based on current technology and large-scale RSSF prototype thermal demonstration testing. However, further study is warranted for the radiant heat transfer from the spent fuel pin assembly to the canister wall due to the complex nature caused by the intricate physical geometry.

Sealed Storage Cask Concept (Nonventilated and With Single Canister of SURF) (SSCC-1)

Heat remnval is based on current technology. Cask fabrication utilizes standard reinforced concrete techniques. However, additional testing of prototypes may be required to provide criteria for the final design of the storage units.

Sealed Storage Cask Concept (Nonventilated and with Multiple Canisters of SURF) (SSCC-2)

The same as with the preceding concept (SSCC-1) 
Air-Cooled Vault Concept (ACVC)

Design and construction of all components and facilities are within current engineering practice. The effects of wind speed and detection of internal air flow, and flow distribution in a partially filled vault will require further study.

Drywell Concept (DWSC-1)

Design and construction of all components and facilities are within current engineering practice and technology. Additional testing, as described for the nonventilated concept (SSCC-1) would also be required for this concept.

Drywell Concept (With Heat Pipes) (DWSC-2)

Detailed analysis of the heat pipe heat rejection system will be required to ascertain the advisability of using heat pipes in this application. Potential problems that are associated with the heat pipe concept include the following:

1. Radiation effects on the heat transfer media

2. Performance degradation resulting from bends in the heat pipe required to prevent radiation streaming

3. Performance degradation as a result of ambient vegetation and dirt clogging the corideriser

4. Mechanical damage to heat pipe condenser.

Water Basin Concept (WBSC)

The technology associated with this design is well understood and supported by many years of operational experience in the commercial nuclear power field. 


\section{PRESENT VALUE OF INITIAL CAPITAL COST}

Sheet I

Suggested Weight, 40; Assigned Weight 30

\section{REQUIREMENTS}

A minimum cost facility is to be designed and constructed to store all fuel five years out of reactors through 1990. The cost for increasina storage capacity beyond the initial allocation will be deferred until required. COMPLIANCE

The following costs in 1977 dollars, include engineering-design, escalation, . and contingency. They represent the initial capital expenditure required to place the facility in operation by 1985. (Refer to RHO-LD-2, February 1978, "Engineering Studies Report," Table 10.2.)

Rating

Sealed Storage Cask Concept (Ventilated) (SSCC-RSSF)

$\$ 210,000,000$

Sealed Storage Cask Concept (Nonventilated and With Single

Canister of SURF) (SSCC-1)

$\$ 210,000,000$

Sealed Storage Cask Concept (Nonventilated and With Multiple

Canisters of SURF) (SSCC-2)

$\$ 201,000,000$

Air-Cooled Vault Concept (ACVC)

$\$ 349,000,000$

Drywe 11 Concept (DWSC-1)

$\$ 173,000,000$ 
Drywell Concept (With Heat Pipes) (DWSC-2)

$\$ 342,000,000$

Water Basin Concept (WBSC) 
PRESENT VALUE OF TOTAL CAPITAL COST

Sheet $\mathrm{J}$

Suggested Weight, 40; Assigned Weight 30

\section{REQUIREMENTS}

This item shows present value of the total capital investment for each facility, including initial capital and deferred capital costs and decommissioning costs.

COMPLIANCE

The following costs are in terms of 1977 dollars without escalation. (Refer to RHO-LD-2, February 1978, "Engineering Studies Report," Table 10.2.)

Sealed Storage Cask Concept (Ventilated) (SSCC-RSSF)

Rating

$\$ 264,000,000$

Sealed Storage Cask Concept (Nonventilated and With Single

Canister of SURF) (SSCC-1)

$\$ 263,000,000$

Sealed Storage Cask Concept (Nonventilated and With Multiple

Canisters of SURF)

$\$ 220,000,000$

Air-Cooled Vault Concept (ACVC)

$\$ 569,000,000$

Drywell Concept (DWSC-1)

$\$ 194,000,000$ 
Drywe11 Concept (With Heat Pipes) (DWSC-2)

$\$ 552,000,000$

Water Basin Concept (WBSC)

$\$ 203,000,000$ 


\section{PRESENT VALUE OF TOTAL PROGRAM COST}

Sheet $K$

Suggested Weight, 40; Assigned Weight 30

\section{REQUIREMENTS}

The total program cost should be minimized to the extent possible without compromising the basic SURF Facility criteria as defined in the "Engineering Studies Report" (refer to RHO-LD-2, page 2).

\section{COMPLIANCE}

This data includes total present value of capital and operating program costs through the design life of the facility. (Refer to RHO-LD-2, February 1978, "Engineering Studies Report," Table 10.2.)

Sealed Storage Cask Concept (Ventilated) (SSCC-RSSF) Rating

$\$ 1,756,000,000$

Sealed Storage Cask Concept (Nonventilated and With Single Canister of SURF) (SSCC-1)

$\$ 1,610,000,000$

Sealed Storage Cask Concept (Nonventilated and With Multiple

$$
\text { Canisters of SURF) (SSCC-2) }
$$

$\$ 938,000,000$

Air-Cooled Vault Concept (ACVC)

$\$ 1,187,000,000$

Drywe11 Concept (DWSC-1)

$\$ 833,000,000$

Drywell Concept (With Heat Pipes) (DWSC-2)

$\$ 1,052,000,000$

Water Basin Concept (WBSC)

$\$ 588,000,000$ 


\section{RESOURCE COMMITMENT}

Sheet $L$

Suggested Weight, 20; Assigned Weight 20

\section{REQUIREMENTS}

The use of national resources for the storage of spent nuclear fuel should be minimized to the extent possible for each concept.

\section{COMPLIANCE}

The following resource commitments indicate the approximate requirements for land, concrete, steel, and stainless steel for each SURF Facility concept.

Sealed Storage Cask Concept (Ventilated) (SSCC-RSSF)

Rating

Land (acres)

1,170

Concrete (cubic yards)

$4,300,000$

Steel (tons)

100,000

Stainless Steel $\left(\mathrm{ft}^{2}\right), \quad 145,000$

Sealed Storage Cask Concept (Nonventilated and With Single Canister of SURF) (SSCC-1)

Land (acres)

$$
\begin{array}{r}
1,170 \\
4,300,000 \\
64,000 \\
145,000
\end{array}
$$

Concrete (cubic yards)

Steel (tons)

Stainless Steel $\left(\mathrm{ft}^{2}\right)$

Sealed Storage Cask Concept (Nonventilated and With Multiple

\section{Canisters of SURF) (SSCC-2)}

Land. (acres)

500

Concrete (cubic yards)

Steel (tons)

$1,390,000$

64,100

Stainless Steel $\left(\mathrm{ft}^{2}\right)$ 
Air-Cooled Vault Concept (ACVC)

Land (acres).

Concrete (cubic yards)

300,000

Steel (tons)

107,000

Stainless Steel $\left(f t^{2}\right)$

145,000

Drywe11 Concept (DWSC-1)

$$
1,655
$$

Land (acres)

84,000

Steel. (tons)

180,000

Stainless Steel $\left(\mathrm{ft}^{2}\right)$

145,000

Drywell Concept (With Heat Pipes) (DWSC-2)

260

Land (acres)

630,000

Concrete (cubic yards)

67,000

Stainless Steel $\left(\mathrm{ft}^{2}\right)$

145,000

Water Basin Concept (WBSC)

Land (acres)

100

Concrete (cubic yards)

Steel (tons)

260,000

Stainless Steel $\left(\mathrm{ft}^{2}\right)$

7,800

600,000 


\section{DEGREE OF PASSIVENESS}

Sheet $M$

Suggested Weight, 40; Assigned Weight 40

\section{REQUIREMENTS}

Since the heat rejection system for SURF must remain functional for all credible events, a passive rather than active system should be the primary method of heat removal.

COMPLIANCE

Each SURF storage concept, except for the water basin concept, makes use of a passive type heat removal system. However, some of the concepts may be evaluated as having a greater degree of passiveness due to the inherent aspects of the proposed storage system.

Sealed Storage Cask Concept (Ventilated) (SSCC-RSSF) Rating

The heat rejection system for this concept is basically passive, but does rely on air flow through annular area via vent openings which have the potential for becoming blocked due to wind-blown debris or flora and fauna.

Sealed Storage Cask Concept (Nonventilated and With Single

\section{Canister of SURF) (SSCC-1)}

This concept utilizes a totally passive heat rejection system.

Sealed Storage Cask Concept (Nonventilated and with Multiple

Canisters of SURF) (SSCC-2)

This concept utilizes a passive heat rejection system identical to the preceding concept.

Air-Cooled Vault Concept (ACVC)

The heat rejection system is passive, i.c., no fans, pumps, motors, etc., are required, but potential for accumulation of debris and flora and fauna in the vault openings and around the SURF canisters does exist - which could affect the heat transfer mechanism. The heat rejection system would also be sensitive to local wind and atmospheric conditions. 
Drywe 11 Concept (DWSC-1)

This concept utilizes a totally passive heat rejection system.

Drywell Concept (With Heat Pipes) (DWSC-2)

This concept utilizes a passive heat rejection system (heat pipes), but the potential does exist for possible malfunction of the condenser section of the heat pipe due to accumulation of wind-blown debris.

Water Basin Concept (WBSC)

This concept does not utilize a passive heat rejection system due to the use of pumps, fans, and motors. 
Feature:

Weight:

REQUIREMENTS

COMPLIANCE NOTES

1 Rating

Sealed Storage Cask Concept (Ventilated) (SSCC-RSSF)

Sealed Storage Cask Concept (Nonventilated and With Single Canister of SURF) (SSCC-1)

Sealed Storage Cask Concept (Nonventilated and With Multiple Canisters of SURF) (SSCC-2)

Air-Cooled Vault Concept (ACVC)

Drywe11 Concept (DWSC-1)

Drywel1 Concept (With Heat Pipes) (DWSC-2)

Water Bas in Concept (WBSC) 
CONCEPT EVALUATION - SUMMARY SHEET

CONCEPT RATINGS ${ }^{3}$

\begin{tabular}{|c|c|c|c|c|c|c|c|c|c|}
\hline FEATURE ${ }^{-1}$ & TITLE & WEIGHT $^{2}$ & $\begin{array}{l}\text { SSCC } \\
\text { RSSF } \\
\end{array}$ & SSCC-1 & SSCC-2 & ACVC & DWSC-1 & DWSC-2 & WBSC \\
\hline A & SURF Confinement Method & 40 & 32 & 36 & 33 & 31 & 34 & 29 & 31 \\
\hline B & Radiation Protection & 40 & 33 & 36 & 35 & 32 & 37 & 33 & 35 \\
\hline C & $\begin{array}{l}\text { Resistance to Credible } \\
\text { Events }\end{array}$ & 40 & 30 & 34 & 33 & 25 & 35 & 25 & 31 \\
\hline D & Heat Rejection System & 40 & 30 & 33 & 32 & 30 & 30 & 27 & 35 \\
\hline$E$ & Operating Reliability & 30 & 20 & 28 & 27 & 20 & 29 & 25 & 20 \\
\hline $\mathrm{F}$ & Retrievability & 30 & 20 & 22 & 24 & 20 & 22 & 19 & 28 \\
\hline - $G$ & Leakage Monitoring & 30 & 20 & 26 & 24 & 16 & 27 & 24 & 24 \\
\hline $\mathrm{H}$ & Status of Technology & 20 & 14 & 16 & 15 & 13 & 16 & 9 & 20 \\
\hline I & $\begin{array}{l}\text { Present Value of } \\
\text { Initial Capital Cost }\end{array}$ & 30 & 20 & 21 & 22 & 13 & 26 & 14 & 30 \\
\hline J. & $\begin{array}{l}\text { Present Value of } \\
\text { Total Capital Cost }\end{array}$ & 30 & 20 & 20 & 23 & 11 & 30 & 12 & 28 \\
\hline K & $\begin{array}{l}\text { Present Value of } \\
\text { Total Program Cost }\end{array}$ & 30 & 10 & 10 & 20 & 16 & 24 & 18 & 29 \\
\hline $\mathrm{L}$ & Resource Commitment & 20 & 9 & 9 & 14 & 17 & 13 & 15 & 17 \\
\hline M & $\begin{array}{l}\text { Degree of } \\
\text { Passiveness }\end{array}$ & 40 & 28 & 39 & 37 & 27 & 39 & 29 & 13 \\
\hline $\mathrm{N}$ & Extra & & & & & & & & \\
\hline 0 & Extra & & & & & & & & \\
\hline & TOTALS & 420 & 286 & 330 & 339 & 271 & 362 & 279 & 341 \\
\hline
\end{tabular}

NOTES:

1 See individual rating sheets.

2 It is suggested that a weight from 0 to 20 be placed on ordinary features; more important features should be assigned higher values. These are the agreed to maximum weights by the SURF Storage Concept Selection Team.

3 The ratings for each concept represent the average weight by the SURF Storage Concept Selection Team. 